\title{
Hydrogeochemical Characteristics and Conceptual Model of the Geothermal Waters in the Xianshuihe Fault Zone, Southwestern China
}

\author{
Xiao $\mathrm{Li}^{1}{ }^{1}$ Xun Huang ${ }^{1}$, Xin Liao ${ }^{2}$ and Yunhui Zhang ${ }^{2, *(1)}$ \\ 1 State Key Laboratory of Geological Disaster Prevention and Environmental Protection, Chengdu University \\ of Technology, Chengdu 610059, China; lixiao@cdut.edu.cn (X.L.); huangxun248@163.com (X.H.) \\ 2 Faculty of Geosciences and Environmental Engineering, Southwest Jiaotong University, Chengdu 611756, \\ China; xinliao@swjtu.edu.cn \\ * Correspondence: zhangyunhui0710@163.com; Tel.: +86-1878-198-3608
}

Received: 11 December 2019; Accepted: 9 January 2020; Published: 13 January 2020

check for updates

\begin{abstract}
Abundant geothermal waters have been reported in the Yalabamei, Zhonggu, Erdaoqiao, and Yulingong geothermal areas of the Xianshuihe Fault Zone of western Sichuan, southwestern China. This study focused on the hydrogeochemical evolution, reservoir temperature, and recharge origin of geothermal waters using hydrochemical and deuterium-oxygen (D-O) isotopic studies. Shallow geothermal waters represented by geothermal springs and shallow drilled water wells are divided into two hydrochemical groups: (1) the $\mathrm{Ca}-\mathrm{Na}-\mathrm{HCO}_{3}$ type in the Erdaoqiao area, and (2) $\mathrm{Na}-\mathrm{HCO}_{3}$ in other areas. Deep geothermal waters represented by deep drilled wells are characterized by the $\mathrm{Na}-\mathrm{Cl}-\mathrm{HCO}_{3}$ type. The major ionic compositions of geothermal water are primarily determined by the water-rock interaction with silicate and carbonate minerals. The reservoir temperatures estimated by multi-geothermometries have a range of $63-150{ }^{\circ} \mathrm{C}$ for shallow geothermal water and of $190-210{ }^{\circ} \mathrm{C}$ for deep geothermal water, respectively. The $\delta^{18} \mathrm{O}$ and $\delta \mathrm{D}$ compositions indicated geothermal waters are recharged by meteoric water from the elevation of 2923-5162 $\mathrm{m}$. Based on the aforementioned analyses above, a conceptual model was constructed for the geothermal system in the Xianshuihe fault zone.
\end{abstract}

Keywords: geothermal water; water-rock interaction; geothermometry; recharge origin; Xianshuihe fault zone

\section{Introduction}

Nowadays, energy shortages and environmental pollution are becoming more and more serious and therefore sustainable development is hampered. To address the aforementioned problems, the exploitation and utilization of clean energy are urgently required. Geothermal resources have become a popular clean energy source due to its clean and renewable affinities [1]. Geothermal springs, as an important constituent of geothermal resources, have become a hot research topic so far [2-6].

Abundant geothermal springs have been reported on the Chinese mainland [7]. Most of the high-temperature geothermal springs are distributed in southwestern China, including southern Tibet, western Sichuan, and western Yunnan [8-14]. The Xianshuihe fault zone (XFZ) of western Sichuan is a famous area with a significant number of geothermal springs [15] (Figure 1a,b). Geothermal springs are primarily found in the Yalabamei, Zhonggu, Erdaoqiao, and Yulingong geothermal areas of the XFZ (Figure 1c). Up to now, previous studies have interpreted the genesis of geothermal springs in the Erdaoqiao and Yulingong geothermal areas using geophysical and geochemical methods [16-24]. However, only a few previous investigations analyzed the geothermal springs in the Yalabamei and Zhonggu geothermal areas [25], and thus the conceptual model of the geothermal system is unclear. 
Further research has yet to be conducted to facilitate the exploitation and utilization of the geothermal resource in the XFZ.
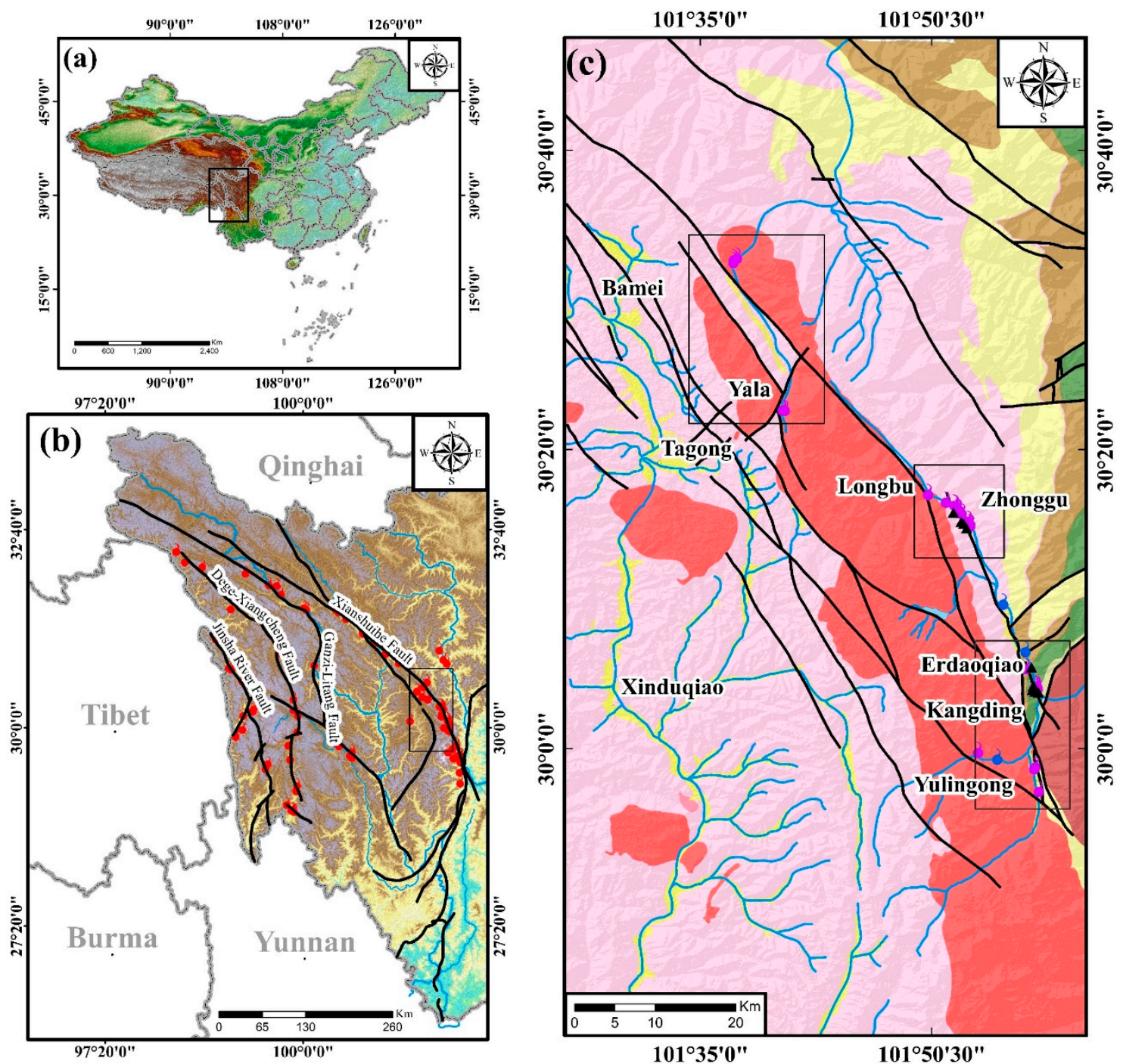

\section{Legend}

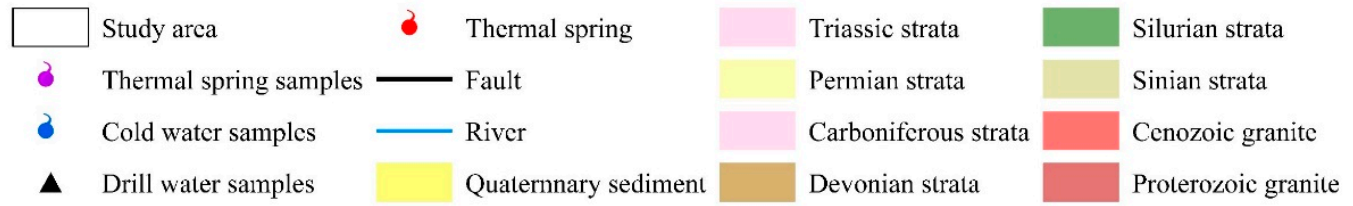

Figure 1. (a) Location of western Sichuan in China, (b) the distribution of geothermal springs in western Sichuan, and (c) the distribution of geothermal springs in the Xianshuihe fault zone.

Therefore, this study aims at clarifying the mechanism of the geothermal system in the XFZ. Forty-one geothermal springs, drilled water wells, and cold water sites were sampled in the Yalabamei, Zhonggu, Erdaoqiao, and Yulingong geothermal areas of the XFZ. Hydrogeochemical and D-O isotopic analyses for those samples were employed to trace the water-rock interaction, reservoir temperature, and recharge source of geothermal water. Afterward, the conceptual model of the geothermal system was preliminarily constructed as a summary of our hydrogeochemical analyses. 


\section{Study Area}

The XFZ is located in southwestern China and tectonically belongs to the eastern margin of the Tibetan Plateau. Since the Eurasian-Indian collision at the Eocene, the XFZ has been moving in the way of the left-lateral strike-slip [26]. The XFZ is composed of northwestern, middle, and southeastern segments. The northwestern segment includes the Luhuo, Daofu, and Bamei faults. The middle segment consists of the Yalahe, Zheduotang, and Selaha faults. The southeastern segment contains the Kangding and Moxi faults. The geomorphology of the XFZ is high mountain and low valley. The elevations of the XFZ have a range of $\sim 3000-7556 \mathrm{~m}$ with a significant difference of 3000-4000 m.

In the study area, the sedimentary strata are dominated by Triassic sandstone and slate with minor Proterozoic marble, schist, and phyllite, Sillure schist and marble, Devonian slate, Permian limestone, and Quaternary sediments. Three periods of magmatic events (the Proterozoic, and early and late Yashanian) have been recognized in the study area. Separated by the XFZ, the Proterozoic igneous rocks are exposed on the eastern side, while early and late Yanshanian igneous rocks are emplaced on the western side.

An abundance of geothermal springs has been investigated in the middle and southeastern segments of the XFZ, heated by deep magma, radioactive heat of granitoids, and strike-slip frictional heat of the XFZ [15]. Their distributions are well controlled by the XFZ, forming the Yalabamei, Zhonggu, Erdaoqiao, and Yulingong geothermal areas (Figure 1c). (1) the Yalabamei area: Twenty geothermal springs with measured temperatures of $47-66^{\circ} \mathrm{C}$ are exposed in the Yanshanian granite. They are mainly distributed along the northeastern-trending faults. (2) The Zhonggu area: More than one hundred geothermal springs have been reported in the Zhonggu area. They are distributed along the Yalahe fault and exposed in the Triassic sandstone. The flow rate ranges from 0.1 to $0.3 \mathrm{~L} / \mathrm{s}$ and the highest temperature is $43^{\circ} \mathrm{C}$. (3) The Erdaoqiao area: The geothermal springs with a discharge of 0.5 to $6.4 \mathrm{~L} / \mathrm{s}$ and a temperature of $32-56{ }^{\circ} \mathrm{C}$ are exposed in the Quaternary sediments along the Yalahe fault. A large number of travertines have been observed on the surface, as well as a strong $\mathrm{H}_{2} \mathrm{~S}$ smell. (4) The Yulingong area: The geothermal springs here have a temperature higher than $60^{\circ} \mathrm{C}$ (the highest is $94^{\circ} \mathrm{C}$ ) and the discharge of $0.24-6.34 \mathrm{~L} / \mathrm{s}$.

\section{Sampling and Methodology}

A total of 36 water samples were collected from geothermal springs, geothermal drilled water wells, and cold springs and rivers in the vicinity of the XFZ on 18-20 May 2017. Field sampling procedures and analytical methodology were described by Zhang et al. (2018) [16]. Temperature, pH, alkalinity, and total dissolved solids (TDS) were measured in the field. Temperatures of the samples were measured using a mercury thermometer. The $\mathrm{pH}$ electrode was calibrated with standard solutions of $\mathrm{pH} 1.0,4.0$, and 7.0. The alkalinity of the samples was measured by Gran titration with $0.1 \mathrm{M} \mathrm{HCl}$ and is expressed here as $\mathrm{HCO}_{3}{ }^{-}$. Samples for cation analysis were filtered through $0.1 \mu \mathrm{m}$ and acidified to $\mathrm{pH}$ less than 1 with $\mathrm{HNO}_{3}$. Anions were determined within $24 \mathrm{~h}$ after collection.

Within a week after fieldwork, all the experiments were carried out in the State Key Laboratory of Geohazard Prevention and Geoenvironment Protection, Chengdu University of Technology. The samples were analyzed for $\mathrm{Si}$ and major cations $(\mathrm{K}, \mathrm{Na}, \mathrm{Ca}$, and $\mathrm{Mg}$ ) using inductively coupled plasma-optical emission spectrometry (ICP-OES) (Thermo Fisher ICAP-6300), while anions ( $\mathrm{Cl}$ and $\mathrm{SO}_{4}$ ) were determined by ion chromatography (Dionex ICS-1100). Charge balance errors between major cations and anions were lower than $\pm 10 \%$ for all samples. The $\delta \mathrm{D}$ and $\delta^{18} \mathrm{O}$ values were reported in delta $(\delta)$ relative to VSMOW (Vienna Standard Mean Ocean Water) using conventional $\delta(\%$ o) notation. The analytical precision for $\delta \mathrm{D}$ and $\delta^{18} \mathrm{O}$ was $\pm 0.6 \%$ and $\pm 0.2 \%$, respectively.

\section{Analytical Results}

The physical properties and chemical compositions of geothermal waters along the Xianshuihe fault are presented in Table S1. The exposed temperature values range from 30.5 to $115^{\circ} \mathrm{C}$, and the 
$\mathrm{pH}$ values vary from 6.5-9.0. Cold spring and river (referred to as cold water afterward) samples have temperature values of $9.8-12.8^{\circ} \mathrm{C}$ and $\mathrm{pH}$ values of 7.9-8.1. $\mathrm{Na}^{+}$and $\mathrm{Ca}^{2+}$ are the primary cations, while $\mathrm{HCO}_{3}{ }^{-}$and $\mathrm{Cl}^{-}$are the dominant anions, respectively (Figure 2). According to the major-ion characteristics of geothermal waters, four representative groups of hydrochemical types were recognized, as shown in Figure 3. The $\mathrm{Na}-\mathrm{HCO}_{3}-\mathrm{Cl}$ type geothermal waters are exposed in the Yulingong area and possess higher TDS and temperature values. The $\mathrm{Ca}-\mathrm{Na}-\mathrm{HCO}_{3}$ type geothermal waters are distributed in the Erdaoqiao area, while $\mathrm{Na}-\mathrm{HCO}_{3}$ type geothermal waters are located in other areas. Both of the $\mathrm{Ca}-\mathrm{Na}-\mathrm{HCO}_{3}$ and $\mathrm{Na}-\mathrm{HCO}_{3}$ type geothermal waters are relatively lower TDS and temperature values. Cold waters are of the $\mathrm{Ca}-\mathrm{HCO}_{3}$ type with the main ions of $\mathrm{Ca}^{2+}$ and $\mathrm{HCO}_{3}{ }^{-}$ (Figure 3).
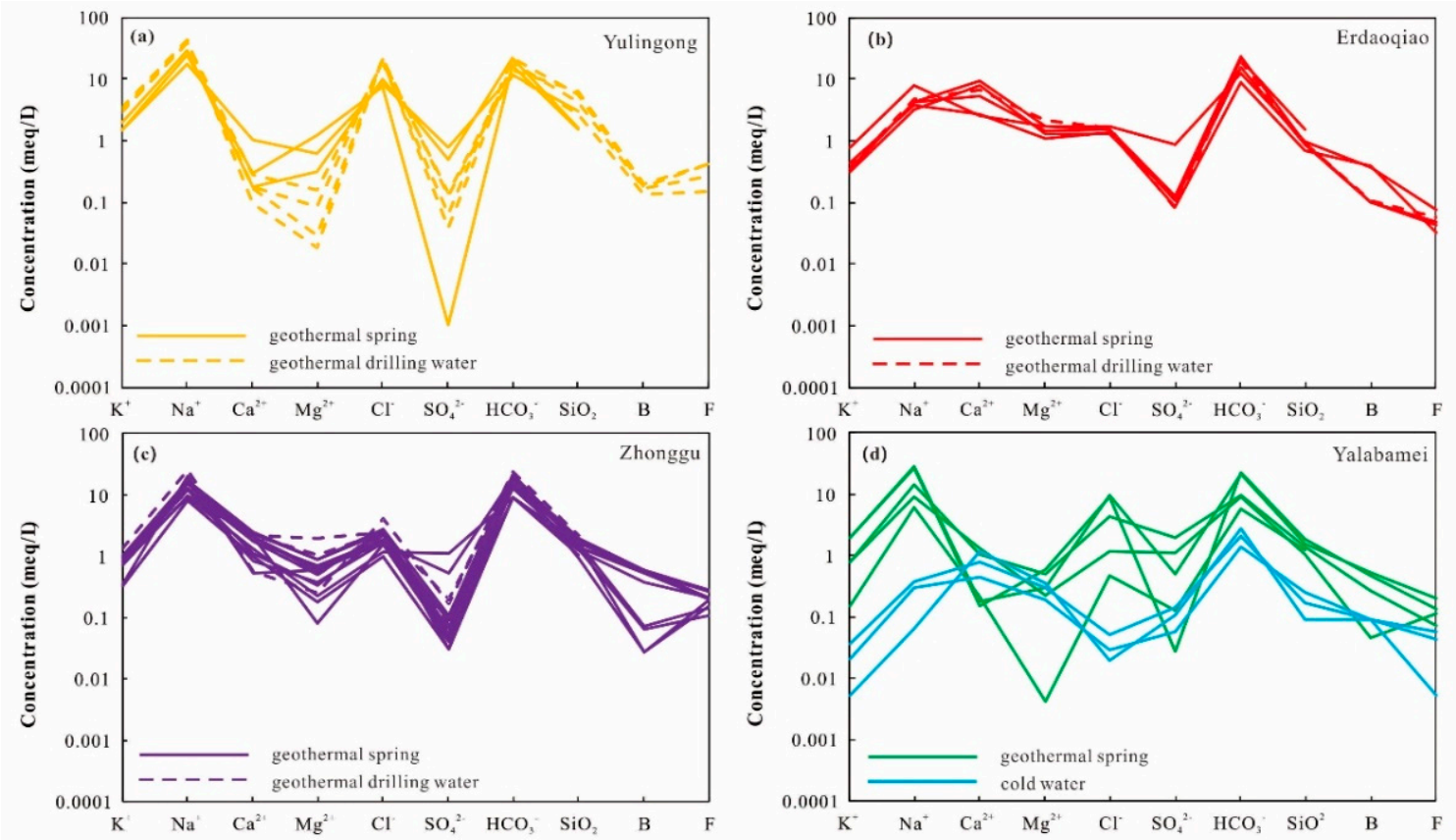

Figure 2. Schoeller semilogarithmic diagram of geothermal water samples from the (a) Yulingong area, (b) Erdaoqiao area, (c) Zhonggu area, and (d) Yalabamei area, with cold water samples here instead of geothermal drilling water.

The concentrations of $\mathrm{SiO}_{2}, \mathrm{~B}$, and $\mathrm{F}$ do not display significant variation among the above four types of geothermal waters (Figure 2). The $\mathrm{SiO}_{2}$ concentrations vary from $42.0 \mathrm{mg} / \mathrm{L}$ to $367.1 \mathrm{mg} / \mathrm{L}$. The highest $\mathrm{SiO}_{2}$ concentrations were observed from the Yulingong drilling holes. The $\mathrm{F}$ concentrations had a range from $0.6 \mathrm{mg} / \mathrm{L}$ to $10 \mathrm{mg} / \mathrm{L}$. The boron concentration (B) are from $0.3 \mathrm{mg} / \mathrm{L}$ to $6.6 \mathrm{mg} / \mathrm{L}$. The small variations of boron concentration imply minor involvements of magmatic composition.

The $\delta^{18} \mathrm{O}$ and $\delta \mathrm{D}$ compositions (vs. Vienna-Standard Mean Ocean Water (VSMOW)) of the sampled waters vary from $-9.3 \%$ o to $-11.4 \%$ ond from $-63.1 \%$ o to $-75.0 \%$, respectively (Supplementary Material: Table S1). The waters in the borate exploration wells were slightly depleted in these two isotopic compositions. 


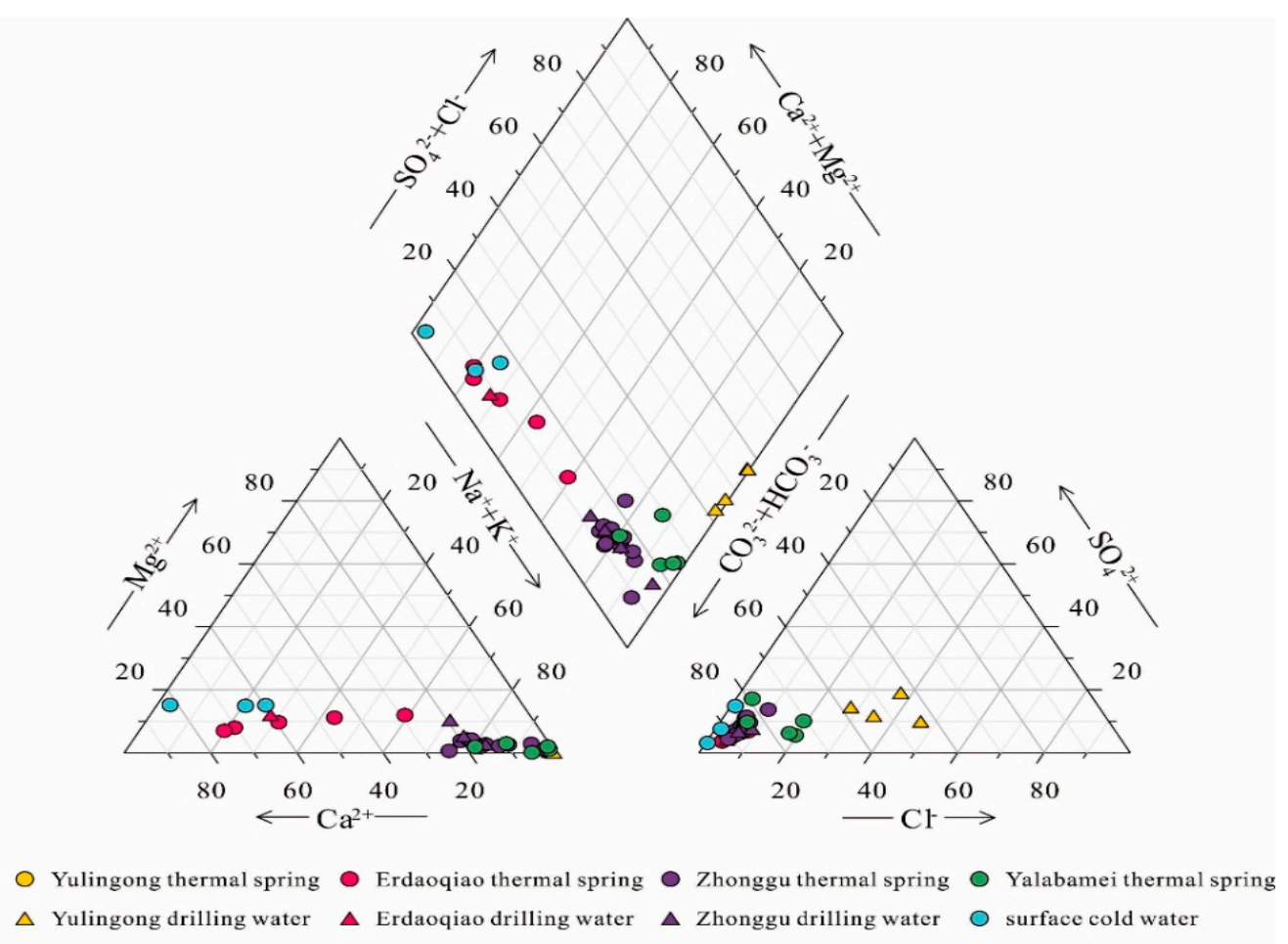

Figure 3. Piper plots of selected cold waters and geothermal waters in the Xianshuihe fault zone (XFZ) [27].

\section{Discussion}

\subsection{Processes Controlling the Major Ionic Compositions}

\subsubsection{Correlations of Major Ions}

Among these major ions, $\mathrm{Cl}$ used to be employed as a useful tool to trace the geochemical process due to its conservative affinity. Even in the condition of high temperatures and high pressures, the $\mathrm{Cl}$ concentration would hardly be altered by water-rock interactions and adsorption of rock-forming minerals. Therefore, the relationship between the $\mathrm{Cl}$ and other major ions is feasible to clarify the hydrochemical processes in the circulation of geothermal waters. In Figure 4, geothermal drill samples are generally around or higher than geothermal spring samples, while cold water samples concentrated around zero with no linear trend. It is observed that $\mathrm{Cl}$ are well correlated with $\mathrm{K}$ (squared regression coefficients $=0.9336$ ) (Figure $4 \mathrm{a}$ ). Geothermal waters are believable to be mixing products between surface cold water and a deep geothermal fluid. Linear relationships between $\mathrm{Na}$ or $\mathrm{SiO}_{2}$ and $\mathrm{Cl}$ concentrations also existed in (Figure $4 b, c)$. However, in comparison, squared regression coefficients (0.8362 and 0.7019 ) of $\mathrm{Na}$ or $\mathrm{SiO}_{2}$ vs. $\mathrm{Cl}$ are obviously lower than that for $\mathrm{K}$ vs. $\mathrm{Cl}$. Considering this, $\mathrm{Na}$ and $\mathrm{SiO}_{2}$ would also be derived from the mixture but may be affected by other processes (e.g., water-rock reaction and ion exchange). The plots of geothermal spring samples above the line of halite dissolution further suggest $\mathrm{Na}$ and $\mathrm{Si}$ were originated from silicate dissolution (Figure 4a). 

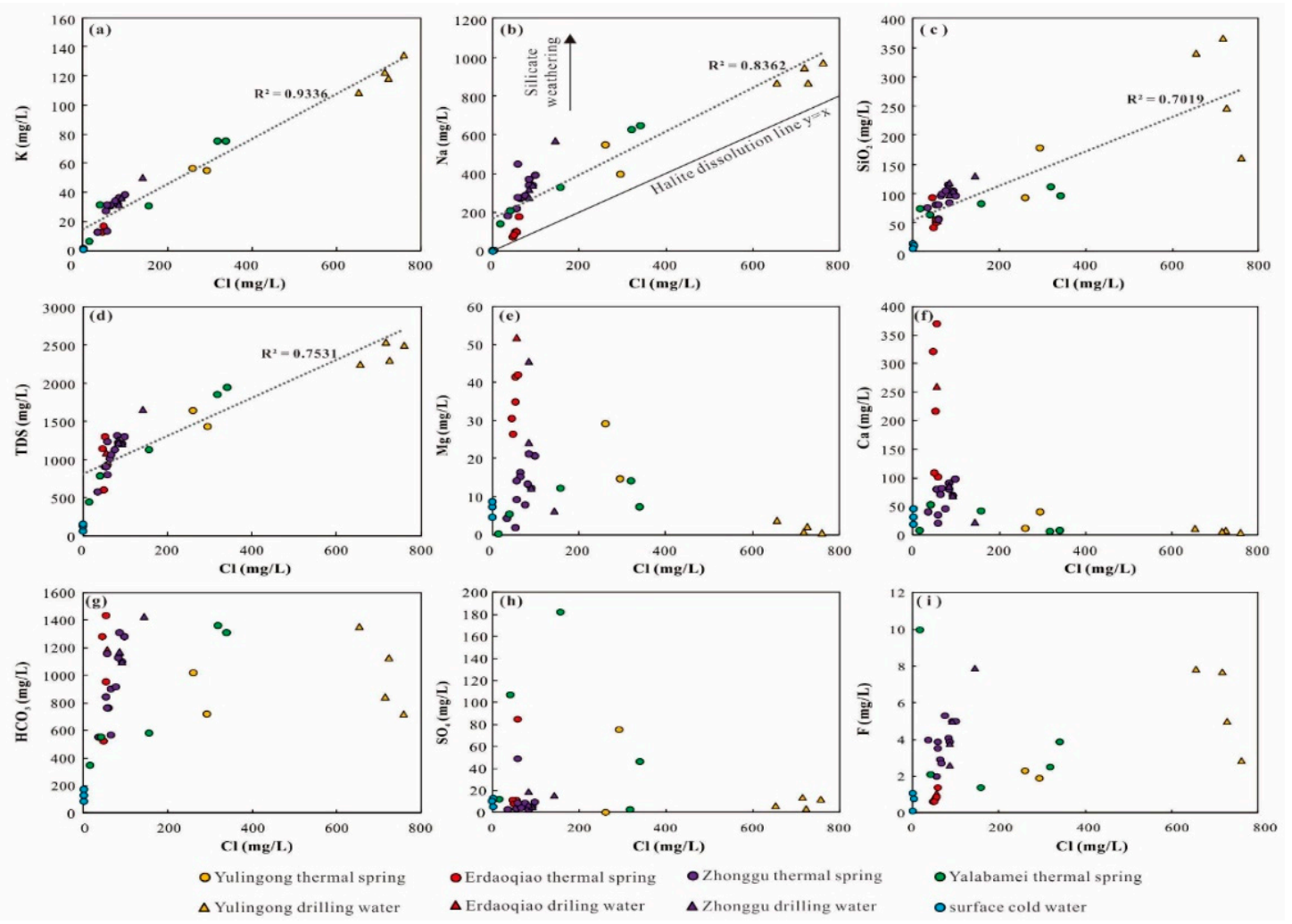

Figure 4. The plots of $\mathrm{Cl}$ against (a) $\mathrm{K}$, (b) $\mathrm{Na}$, (c) $\mathrm{SiO}_{2}$, (d) $\mathrm{TDS},(\mathbf{e}) \mathrm{Mg}$, (f) $\mathrm{Ca}$, (g) $\mathrm{HCO}_{3}$, (h) $\mathrm{SO}_{4}$, and (i) F.

In addition, the plots in the $\mathrm{Ca}, \mathrm{Mg}, \mathrm{HCO}_{3}, \mathrm{SO}_{4}$, and $\mathrm{F}$ vs. $\mathrm{Cl}$ diagrams present scattered distributions (Figure 4e-i). Hence, these ions are suggested to be derived from multiple sources. When the $\mathrm{Ca}^{2+} / \mathrm{HCO}_{3}{ }^{-}$and $\left(\mathrm{Ca}^{2+}+\mathrm{Mg}^{2+}\right) / \mathrm{HCO}_{3}{ }^{-}$molar ratios are equal to 0.5 , those ions are attributed to the dissolution of calcite and dolomite (Equations (1) and (2)).

$$
\begin{aligned}
\mathrm{CaCO}_{3} \text { (calcite) }+\mathrm{H}_{2} \mathrm{CO}_{3} & \rightarrow \mathrm{Ca}^{2+}+2 \mathrm{HCO}_{3}^{-} \\
\mathrm{CaMg}\left(\mathrm{CO}_{3}\right)_{2} \text { (dolomite) }+2 \mathrm{H}_{2} \mathrm{CO}_{3} & \rightarrow \mathrm{Ca}^{2+}+\mathrm{Mg}^{2+}+4 \mathrm{HCO}_{3}{ }^{-}
\end{aligned}
$$

In Figure $5 \mathrm{a}$, the $\mathrm{Ca}^{2+} / \mathrm{HCO}_{3}{ }^{-}$and $\left(\mathrm{Ca}^{2+}+\mathrm{Mg}^{2+}\right) / \mathrm{HCO}_{3}{ }^{-}$molar ratios are lower than 0.5. The low $\mathrm{Ca}^{2+}$ and enrichment of $\mathrm{HCO}_{3}{ }^{-}$are attributed to ion exchange from silicates dissolution.

When the $\mathrm{Ca}^{2+}$ and $\mathrm{SO}_{4}^{2-}$ are derived from dissolution of gypsum, the ratio between $\mathrm{Ca}^{2+}$ and $\mathrm{SO}_{4}{ }^{2-}$ would be 1:1 (Equation (3)).

$$
\mathrm{CaSO}_{4} \cdot 2 \mathrm{H}_{2} \mathrm{O} \rightleftarrows \mathrm{Ca}^{2+}+\mathrm{SO}_{4}{ }^{2-}+2 \mathrm{H}_{2} \mathrm{O}
$$

In this study, most of the samples are plotted distinctly below 1:1 line in $\mathrm{Ca}^{2+}$ versus $\mathrm{SO}_{4}{ }^{2-}$ diagram (Figure 5c), indicating the significantly higher concentration of $\mathrm{Ca}^{2+}$. Hence, the enriched $\mathrm{Ca}^{2+}$ would be produced from the dissolution of carbonates and silicate minerals.

In the $(\mathrm{Na}+\mathrm{K})-\mathrm{Cl}$ and $(\mathrm{Ca}+\mathrm{Mg})-\left(\mathrm{SO}_{4}+\mathrm{HCO}_{3}\right)$ diagram, most of the samples are plotted along the 1:1 line. Hence, the hydrochemical composition of the samples are controlled by a cation-exchange process that is the result of silicate dissolution (Figure $5 \mathrm{~d}$ ). 

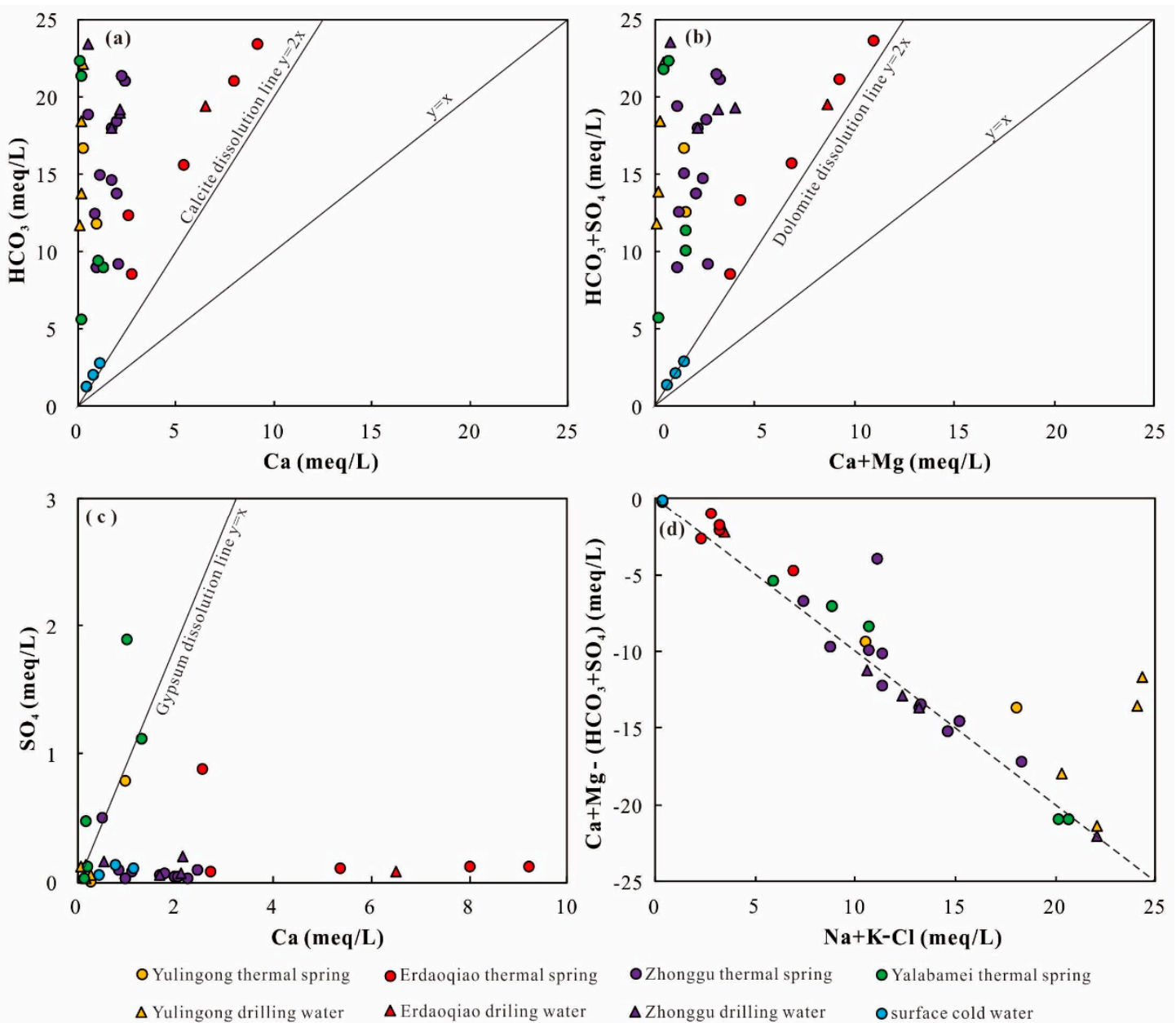

Figure 5. Diagrams used to identify hydrogeochemical processes based on the concentrations of major constituents in water. (a) Ca vs. $\mathrm{HCO}_{3}$, (b) $\mathrm{Ca}+\mathrm{Mg}$ vs. $\mathrm{HCO}_{3}+\mathrm{SO}_{4}$ (c) $\mathrm{Ca}$ vs. $\mathrm{SO}_{4}$, and (d) $\mathrm{Na}+\mathrm{K}-$ $\mathrm{Cl}$ vs. $\mathrm{Ca}+\mathrm{Mg}-\left(\mathrm{HCO}_{3}+\mathrm{SO}_{4}\right)$.

\subsubsection{Principle Component Analysis}

Hydrochemical parameters including $\mathrm{pH}$ and major ions were used for principal component analysis, which is helpful for tracing the sources of those ions $[16,17]$. The results of the principal component analysis include eigenvalue, percentage of variance, the cumulative percentage of variance, and the factor loading, presented in Table 1. Scree plots for groundwater samples showed a distinct change of slope after the second factor (Figure 6a). Using the Kaiser Criterion and scree plot, two principal components (PCs) of eigenvalues greater than 1 have been obtained, accounting for a total variance of $73.084 \%$. The PC1 was responsible for $55.250 \%$ of the total variance and has a strong loading of TDS, $\mathrm{Na}^{+}, \mathrm{K}^{+}, \mathrm{Cl}^{-}$and $\mathrm{SiO}_{2}$ (Figure $6 \mathrm{~b}$ ). This factor indicates the general trend of hydrochemical characteristics, probably dominated by the mixture between cold surface water, deep geothermal water, and the dissolution of silicate minerals. The PC2 explained $17.835 \%$ of the total variance and has a medium positive loading of $\mathrm{Ca}^{2+}, \mathrm{Mg}^{2+}$, and $\mathrm{HCO}_{3}{ }^{-}$(Figure 6b). As such, $\mathrm{PC} 2$ could be linked to the dissolution of limestone and dolomite.

Based on the analyses of correlations of major ions and the principal component analysis, it is possible to constrain the sources of different water types in the XFZ. The $\mathrm{Na}-\mathrm{HCO}_{3}-\mathrm{Cl}$ type geothermal waters would be derived from the dissolution of silicate rocks with the mixing of deep fluids. $\mathrm{Na}-\mathrm{HCO}_{3}$ type geothermal waters are the products from the dissolution of silicate rocks, while $\mathrm{Ca}-\mathrm{Na}-\mathrm{HCO}_{3}$ type geothermal waters are originated from the dissolution of silicate and carbonate rocks. 
Table 1. Factor loadings and eigenvalues of the eleven extracted factors.

\begin{tabular}{ccc}
\hline Variables & PC1 & PC2 \\
\hline $\mathrm{K}$ & 0.9653 & -0.0195 \\
$\mathrm{Na}$ & 0.9840 & -0.0203 \\
$\mathrm{Ca}$ & -0.5575 & 0.6614 \\
$\mathrm{Mg}$ & -0.4390 & 0.7169 \\
$\mathrm{Cl}$ & 0.9452 & -0.0088 \\
$\mathrm{SO}_{4}$ & -0.0993 & -0.4763 \\
$\mathrm{HCO}_{3}$ & 0.2919 & 0.8155 \\
$\mathrm{~T}$ & 0.7142 & 0.1942 \\
$\mathrm{pH}$ & 0.7764 & 0.0826 \\
$\mathrm{TDS}$ & 0.9387 & 0.2700 \\
$\mathrm{SiO}$ & 0.8315 & -0.0133 \\
Eigenvalue & 6.0770 & 1.9620 \\
Variance $(\%)$ & 55.25 & 17.835 \\
Cumulative $(\%)$ & 55.25 & 73.0840 \\
\hline
\end{tabular}
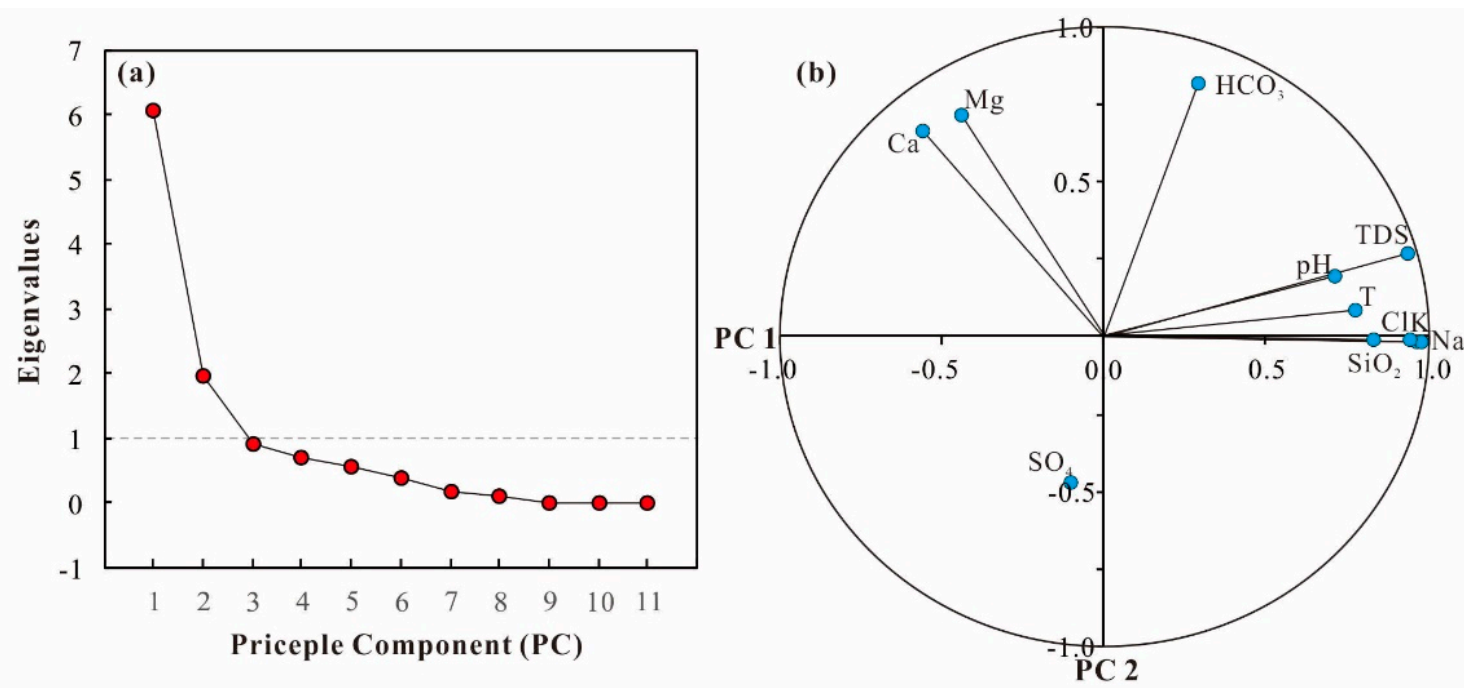

Figure 6. Diagrams of principle component analysis, (a) scree plot, (b) factor loadings for PC1 and PC2.

\subsection{Geothermometry}

Geothermometers are used to estimate reservoir temperatures for most systems. The geothermometers are based on temperature-dependent, water-rock equilibria that control the chemical and isotopic composition of geothermal waters. The temperature of the reservoir associated with the geothermal system of the XFS was estimated using both classical geothermometers (cation and silica), the silicon-enthalpy graphic method, and geothermometrical modeling.

\subsubsection{Classical Geothermometry}

The classic chemical geothermometers (e.g., cation and silica) are applicable for the estimation of the equilibrium temperature in geothermal reservoirs. Considering this, cation and silica geothermometers were conducted to calculate the equilibrium temperatures as listed in Table S1. However, the results from the cation geothermometers have a great range and have a large variation with wellhead temperatures. In the $\mathrm{Na}-\mathrm{K}-\mathrm{Mg}$ ternary diagram, most of the samples are located in the area of immature water, whereas only the samples of the Yulingong deep wells are found in semi-mature fields (Figure 7). The diagram demonstrates that none of the geothermal spring waters have reached full equilibrium with the host. Therefore, Silica geothermometers are more applicable to the geothermal spring waters than cation geothermometers in this study [28]. 


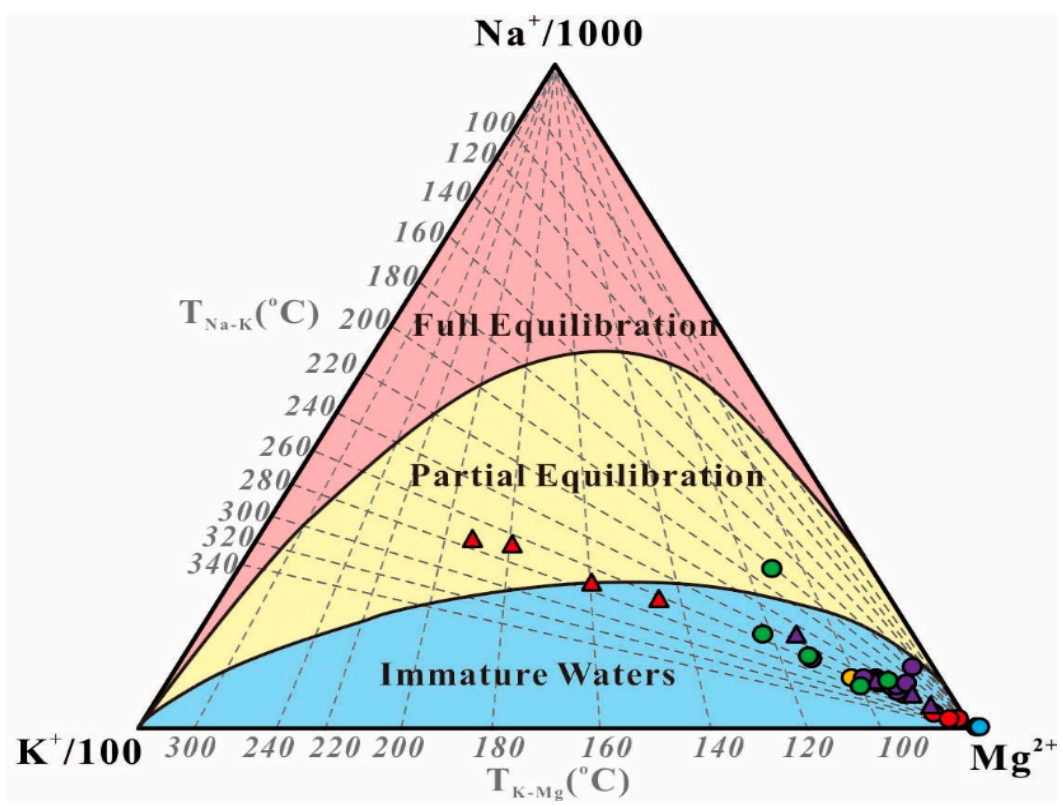

Figure 7. Na-K-Mg trilinear equilibrium diagram of the geothermal waters in the XFZ [28]. Legends are followed by those in Figure 5.

Silica geothermometry is based on the solubility of different silica species (mostly e.g., quartz, chalcedony) in water as a function of reservoir temperature. In Table S1 (see Supplementary Material) estimated reservoir temperatures in the study area using various silica geothermometers are presented. The plots in the $\log \left(\mathrm{K}^{2} / \mathrm{Mg}\right)$ versus the $\log \left(\mathrm{SiO}_{2}\right)$ diagram shows most of the samples are distributed above the chalcedony curve (Figure 8). The chalcedony saturation indices higher than zero indicate the chalcedony is oversaturated. In addition, quartz geothermometers are used for relatively high temperatures, but at temperatures lower than $180^{\circ} \mathrm{C}$, chalcedony may control the dissolved silica concentration in geothermal fluids. The estimated reservoir temperatures are mostly lower than $180^{\circ} \mathrm{C}$. Consequently, the chalcedony geothermometer is the most appropriate silica geothermometer to estimate reservoir temperatures of the geothermal springs, yielding the results from $63-150{ }^{\circ} \mathrm{C}$.

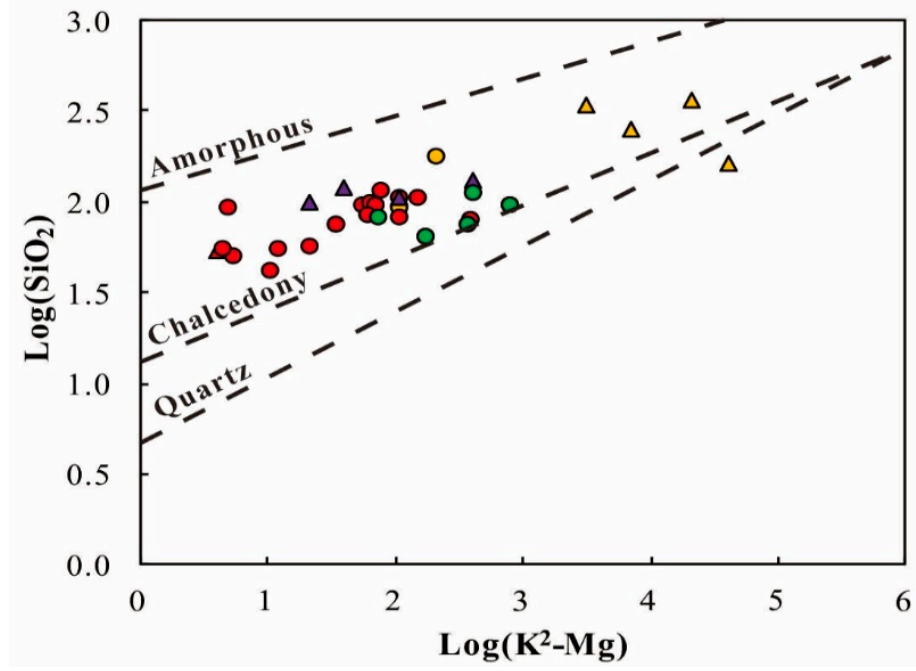

Figure 8. Cross plots of $\log \left(\mathrm{K}^{2} / \mathrm{Mg}\right)$ vs. $\log \left(\mathrm{SiO}_{2}\right)$ of the geothermal waters in the XFZ [29]. Legends follow those in Figure 5. 


\subsubsection{Silicon-Enthalpy Graphic Method}

Due to the immature affinity of geothermal waters, the mixing of cold water should be considered in the calculation of reservoir temperature [30]. As such, it is reliable to use for estimating the reservoir temperature of mixed geothermal water. In this study, cold and geothermal water samples are plotted in the silica enthalpy mixing model and the silica concentration and corresponding enthalpies are determined by the international steam tables [31].

Figure 9 presents the silica-enthalpy mixing model according to chalcedony and quartz solubilities. Two end-member fluids have been given in this model: the cold water sample as one end member and the geothermal waters as the other end member. A red line linking deep geothermal well water and steam point intersected with the Quartz solubility line at the point a. The point stands for the enthalpies/temperatures for the deep. A purple line was drawn from cold water to the geothermal springs and intersected with the Quartz solubility line at the point $b$. The horizontal axis of the point $\mathrm{b}$ is the reservoir temperature in the condition of no steam separation before mixing. A horizontal blue line is drawn at the intersection between the purple line and the vertical line of the boiling point of water intersected with the maximum steam loss line at point $c$. The horizontal axis of the point $\mathrm{c}$ is the reservoir temperature in the condition of steam separation occurs before mixing. Based on the aforementioned above, the estimated reservoir temperatures of deep geothermal well water and geothermal springs are $208^{\circ} \mathrm{C}, 265^{\circ} \mathrm{C}$ (no steam separation before mixing), and $164^{\circ} \mathrm{C}$ (maximum steam loss before mixing), respectively. It is noted that the temperature of deep geothermal well water is lower than that of the geothermal spring. This phenomenon would be attributed to $\mathrm{CO}_{2}$ degassing that leads to the $\mathrm{SiO}_{2}$ reprecipitate. The reservoir temperatures $\left(63-150^{\circ} \mathrm{C}\right)$ estimated by the chalcedony geothermometer are compatible with the temperature $\left(164^{\circ} \mathrm{C}\right)$ in the condition of maximum steam loss before mixing. Therefore, the reservoir temperature determined by the silica-enthalpy mixing model is approximately $164{ }^{\circ} \mathrm{C}$ when no steam separation occurred before mixing. In addition, the mixture ratio of cold water can be estimated by the length of point $b$ and the end-member of the geothermal spring against the length of point $b$ and the end-member of cold water (Figure 9). As such, the mixture ratios of cold water are about $70-90 \%$.

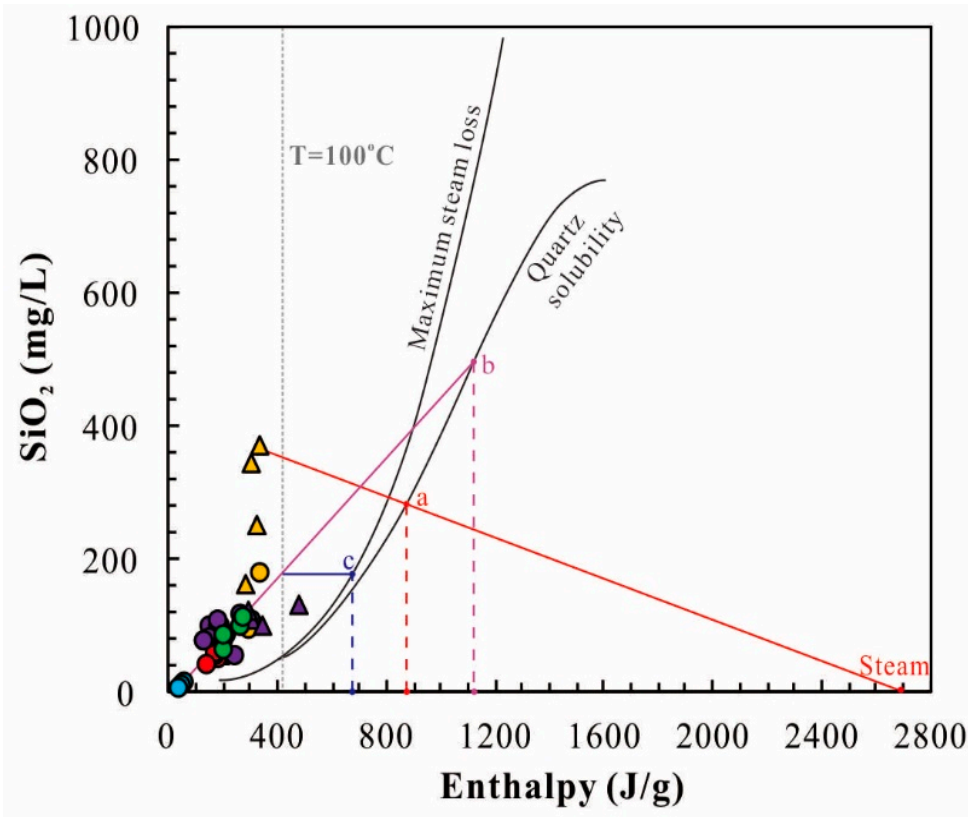

Figure 9. The silica-enthalpy plot of the geothermal waters and cold waters in the XFZ. Legends follow those in Figure 5. 


\subsubsection{Geothermometrical Modeling}

A multi-mineral saturation geothermometer is employed to estimate reservoir temperature when the geothermal water in the reservoir reaches mineral equilibrium [32]. In this study, the variations of the saturation indices of different mineral temperatures were calculated at a temperature step of $20^{\circ} \mathrm{C}$ using SOLVEQ-XPT. The two samples with the highest wellhead temperatures (HKJ02 and HKJ03, see in Table S1) are taken as the representatives for the Yulingong area. To correct $\mathrm{CO}_{2}$ degassing and possible aluminum concentration error, the calcite and microcline were forced to reach mineral equilibrium. For the geothermal wells (HKJ02 and HKJ03), saturation indices (SI) with respect to albite, aragonite, calcite, chalcedony, dolomite, quartz, laumontite, fluorite microcline, K-feldspar, illite, $\mathrm{SiO}_{2}(\mathrm{a})$, chlorite, and montmorillonite minerals tend to get closer to zero $(\mathrm{SI}=0)$ around the temperature of $200-210{ }^{\circ} \mathrm{C}$ and $190-200{ }^{\circ} \mathrm{C}$ (Figure 10). The temperature range indicates the estimated reservoir temperature at which these minerals reach an equilibrium condition. Meanwhile, the estimated reservoir temperatures estimated by the multi-mineral saturation geothermometer are consistent with the estimated reservoir temperature $\left(208^{\circ} \mathrm{C}\right)$ obtained by the silicon-enthalpy graphic method.
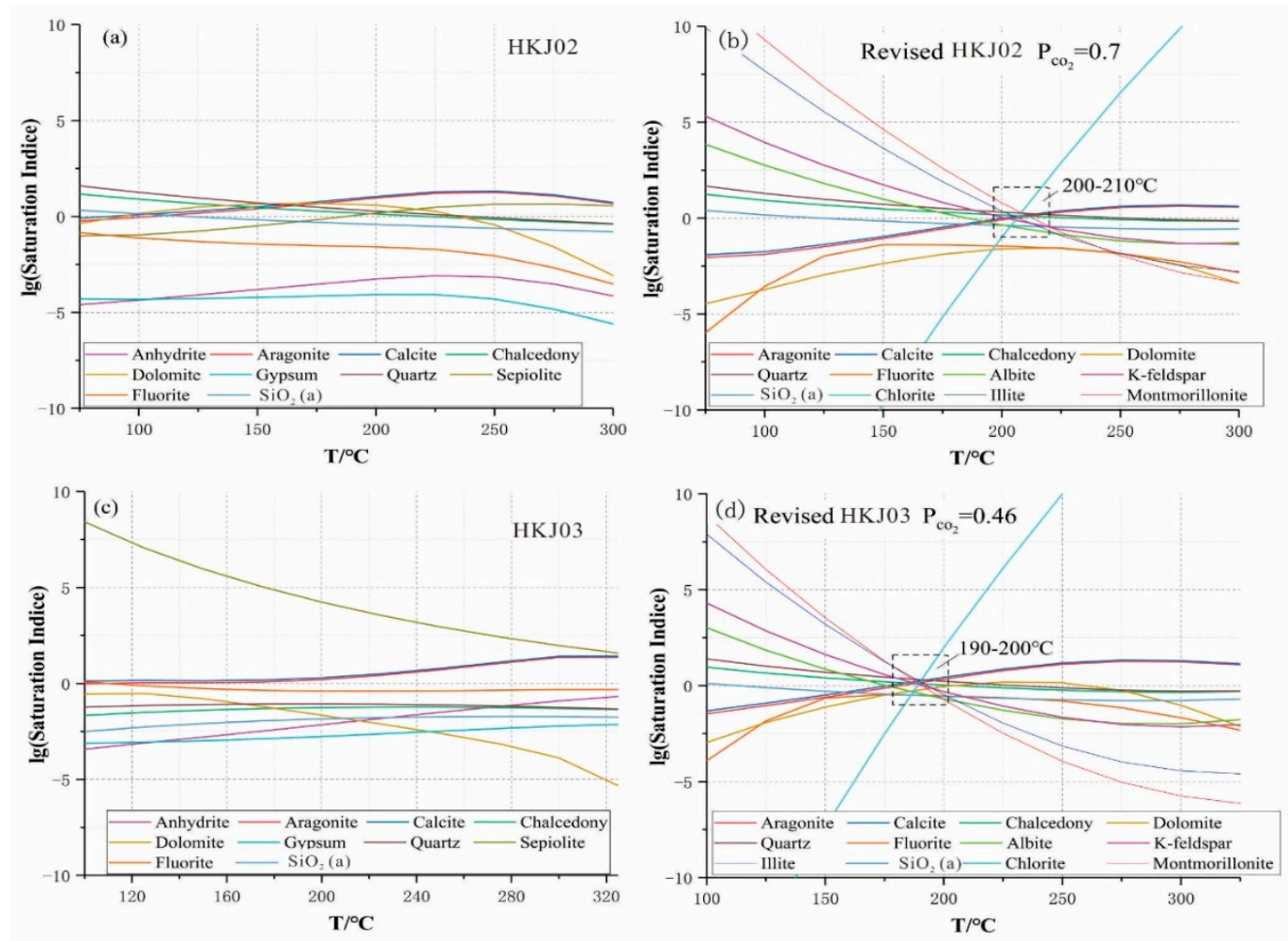

Figure 10. Initial and reconstructed mineral equilibria graph of representative drilling water samples $\mathrm{HKJO2}(\mathbf{a}, \mathbf{b})$ and HKJ03 (c,d).

\subsection{Recharge Origin Traced by $\delta D$ and $\delta^{18} \mathrm{O}$}

$\mathrm{H}$ and $\mathrm{O}$ stable isotopes ( $\delta \mathrm{D}$ and $\delta^{18} \mathrm{O}$ ) are useful to trace the recharge origin of surface and ground waters. In this study, the $\delta \mathrm{D}$ and $\delta^{18} \mathrm{O}$ values of geothermal waters range from $-138.5 \%$ o to $-113.8 \%$ o (average $=-125.9 \%$ o) and $-18.0 \%$ o to $-14.7 \%$ o (average $=-16.5 \%$ o), respectively (Table S1). The geothermal waters are plotted close to the Global Meteoric Water Line (GMWL) [33] in the $\delta \mathrm{D}-\delta^{18} \mathrm{O}$ graph, suggesting recharge origin of meteoric water (Figure 11). It is noteworthy that the plots of geothermal waters are slightly deviated from the global meteoric water line (GMWL), representing the occurrence of oxygen-isotope drifting. This phenomenon may be attributed to the oxygen isotope exchange by the water-rock reaction between geothermal waters and the surrounding carbonate or silicate rocks (calcite or silicate). 


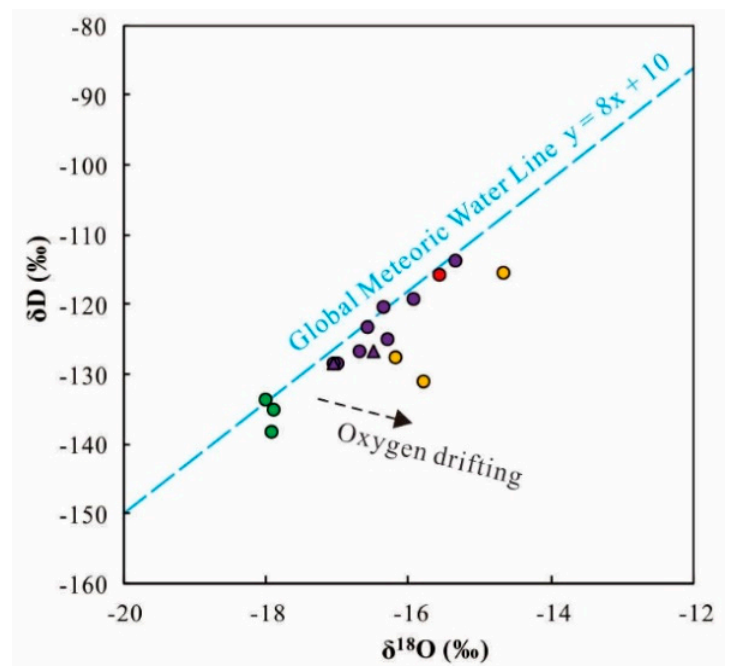

Figure 11. Plot of $\delta^{18} \mathrm{O}-\delta \mathrm{D}$ for the geothermal waters in the XFZ. Global meteoric water line (GWML) is after [33]. Legends follow those in Figure 5.

Due to the altitude effect of $\delta \mathrm{D}$ and $\delta^{18} \mathrm{O}$, they can be used to calculate the recharge elevation. Considering the existence of oxygen drifting, the $\delta \mathrm{D}$ values of the geothermal waters are more robust to estimate the recharge elevation in this study. The recharge elevations of geothermal water are calculated based on Equation (4) below [33]:

$$
\mathrm{H}=\mathrm{h}+(\delta \mathrm{S}-\delta \mathrm{P}) / \mathrm{K}
$$

where $\mathrm{H}$ is the recharge elevation $(\mathrm{m}), \mathrm{h}$ is the reference point elevation, $\delta \mathrm{S}$ is the $\delta \mathrm{D}$ or $\delta^{18} \mathrm{O}$ value of sampled geothermal waters, $\delta \mathrm{P}$ is the $\delta \mathrm{D}$ or $\delta^{18} \mathrm{O}$ value of recharge water, and $\mathrm{K}$ is the $\delta \mathrm{D}$ or $\delta^{18} \mathrm{O}$ elevation gradient of atmospheric precipitation $(\delta / 100 \mathrm{~m})$. In this study case, $\mathrm{h}$ is $270 \mathrm{~m}, \delta \mathrm{P}$ is $-52.9 \%$ or for $\delta \mathrm{D}$ and $-7.0 \%$ o for $\delta^{18} \mathrm{O}$, and $\mathrm{K}$ is $-1.12 \%$ o/ $100 \mathrm{~m}$ for $\delta \mathrm{D}$ and $-0.26 \% / 100 \mathrm{~m}$ for $\delta^{18} \mathrm{O}$ [34]. Accordingly, the recharge elevation of the geothermal waters in the XFZ are calculated as 2923-5162 m (Table S1).

\subsection{Conceptual Model}

Based on the available geochemical, structural, and hydrogeological data, the following conceptual model is proposed, integrated in Figure 12.

A previous study proposed the geothermal system of the XFZ is a liquid-dominated system heated by deep magma, radioactive heat of granitoids, and strike-slip frictional heat. D-O isotopes indicate geothermal water is recharged by meteoric water with precipitation elevation of $2923-5162 \mathrm{~m}$ and then travel along the developed faults and fractures of the XFZ. Water-rock is common in the circulation of geothermal water because of obvious $\delta^{18} \mathrm{O}$ drifting. The major ions (e.g., $\mathrm{Na}^{+}, \mathrm{Ca}^{2+}$ and $\mathrm{HCO}_{3}{ }^{-}$) of geothermal water are derived from the dissolution of silicate and carbonate minerals and ion exchange. Shallow geothermal water with $\mathrm{Ca}-\mathrm{HCO}_{3}$ or $\mathrm{Na}-\mathrm{HCO}_{3}$ types is produced by the mixture between $\mathrm{Na}-\mathrm{Cl}-\mathrm{HCO}_{3}$ type deep geothermal water and $\mathrm{Ca}-\mathrm{HCO}_{3}$ surface cold water. Deep and shallow geothermal waters possess the reservoir temperatures of $63-150{ }^{\circ} \mathrm{C}$ and $190-210{ }^{\circ} \mathrm{C}$, respectively. No steam separation occurred before mixing. Finally, geothermal water arises and emerges as geothermal spring in the area where faults and fractures exist, mixed by $70 \%-90 \%$ cold water. 


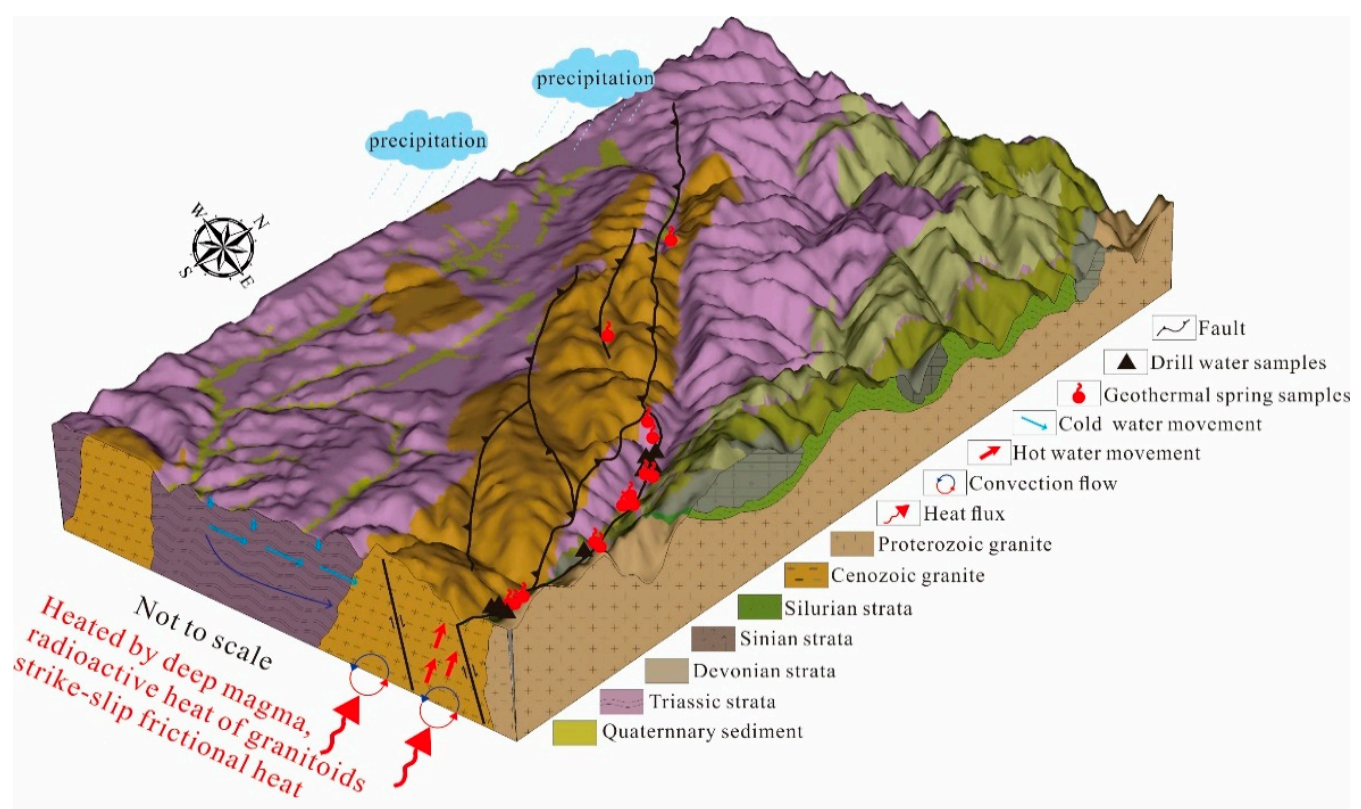

Figure 12. Preliminary conceptual model of the geothermal system in the XFZ.

\section{Conclusions}

The physical and chemical processes controlling the chemical composition of the geothermal waters in the XFS were investigated. In this context, the results obtained from geochemical and isotopic studies are listed below.

1. Shallow geothermal waters represented by geothermal springs and shallow drilled wells are divided into two hydrochemical groups: (1) $\mathrm{Ca}-\mathrm{Na}-\mathrm{HCO}_{3}$ type in the Erdaoqiao area, and (2) $\mathrm{Na}-\mathrm{HCO}_{3}$ in other areas. Deep geothermal waters represented by deep drilled wells are characterized by $\mathrm{Na}-\mathrm{Cl}-\mathrm{HCO}_{3}$ type. Cold waters are of the $\mathrm{Ca}-\mathrm{HCO}_{3}$ type.

2. Correlations of major ions and principle component analyses agree that the major ionic compositions of geothermal water are primarily determined by the water-rock interaction with silicate and carbonate minerals.

3. Silica and silicon enthalpy graphic method and geothermometrical modeling yield the reservoir temperatures of $63-150{ }^{\circ} \mathrm{C}$ for shallow geothermal waters, and of $190-210{ }^{\circ} \mathrm{C}$ for shallow geothermal waters, respectively. Cold water at $70-90 \%$ was proposed to be mixed with geothermal water.

4. The $\delta^{18} \mathrm{O}$ and $\delta \mathrm{D}$ compositions indicated geothermal waters are recharged by meteoric water from the elevation of 2923-5162 m. Oxygen drifting implies the occurrence of water-rock interaction in the formation of geothermal waters.

Supplementary Materials: The following are available online at http://www.mdpi.com/1660-4601/17/2/500/s1, Table S1: Hydrochemical and $\delta^{18} \mathrm{O}$ and $\delta \mathrm{D}$ compositions of geothermal and cold waters in the Xianshuihe Fault Zone.

Author Contributions: Data curation, X.H.; Formal analysis, X.H. and X.L. (Xin Liao).; Funding acquisition, X.L. (Xiao Li); Investigation, Y.Z.; Project administration, X.L. (Xiao Li); Software, X.L. (Xin Liao); Supervision, Y.Z.; Visualization, X.H.; Writing-original draft, X.L. (Xiao Li) and Y.Z. All authors have read and agreed to the published version of the manuscript.

Funding: This research received no external funding.

Acknowledgments: We thank anonymous reviewers and the Editor-in-Chief for their constructive comments. We thank Jing Yu and Ziwen Hu at the State Key Laboratory of Geohazard Prevention and Geo-environment Protection, Chengdu University of Technology for their assistance and helpful discussions.

Conflicts of Interest: The authors declare no conflict of interest. 


\section{References}

1. Lund, J.W.; Freeston, D.H.; Boyd, T.L. Direct application of geothermal energy: 2005 Worldwide review. Geothermics 2005, 34, 691-727. [CrossRef]

2. Nukman, M.; Hochstein, M.S.P. The sipoholon geothermal field and adjacent geothermal systems along the north-central sumatra fault belt, indonesia: Reviews on geochemistry, tectonics, and natural heat loss. J. Asian Earth Sci. 2019, 170, 316-328. [CrossRef]

3. Minissale, A.; Donato, A.; Procesi, M.; Pizzino, L.; Giammanco, S. Systematic review of geochemical data from thermal springs, gas vents and fumaroles of Southern Italy for geothermal favourability mapping. Earth Sci. Rev. 2019, 188, 514-535. [CrossRef]

4. Chenaker, H.; Houha, B.; Vincent, V. Hydrogeochemistry and geothermometry of thermal water from north-eastern Algeria. Geothermics 2018, 75, 137-145. [CrossRef]

5. Montanari, D.; Minissale, A.; Doveri, M.; Gola, G.; Trumpy, E.; Santilano, A.; Manzella, A. Geothermal resources within carbonate reservoirs in western Sicily (Italy): A review. Earth Sci. Rev. 2017, 169, 180-201. [CrossRef]

6. Iskandar, I.; Dermawan, F.A.; Sianipar, J.Y.; Notosiswoyo, S. Characteristic and mixing mechanisms of thermal fluid at the tampomas volcano, west java, using hydrogeochemistry, stable isotope and ${ }^{222} \mathrm{Rn}$ analyses. Geosciences 2018, 8, 103. [CrossRef]

7. Pang, Z.H.; Kong, Y.L.; Shao, H.B.; Kolditz, O. Progress and perspectives of geothermal energy studies in China: From shallow to deep systems. Environ. Earth Sci. 2018, 77, 580-584. [CrossRef]

8. Tang, X.; Zhang, J.; Pang, Z.; Hu, S.; Tian, J.; Bao, S. The eastern Tibetan Plateau geothermal belt, western China: Geology, geophysics, genesis, and hydrothermal system. Tectonophysics 2017, 717, 433-448. [CrossRef]

9. Guo, Q. Hydrogeochemistry of high-temperature geothermal systems in China: A review. J. Appl. Geochem. 2012, 27, 1887-1898. [CrossRef]

10. Zhang, X.; Hu, Q. Development of geothermal resources in China: A review. J. Earth Sci. 2018, 2, $452-467$. [CrossRef]

11. Tian, J.; Pang, Z.; Guo, Q.; Wang, Y.; Li, J.; Huang, T.; Kong, Y. Geochemistry of geothermal fluids with implications on the sources of water and heat recharge to the Rekeng high-temperature geothermal system in the Eastern Himalayan Syntax. Geothermics 2018, 74, 92-105. [CrossRef]

12. Wang, C.; Zheng, M. Hydrochemical Characteristics and evolution of hot fluids in the gudui geothermal field in comei county, himalayas. Geothermics 2019, 81, 243-258. [CrossRef]

13. Wang, X.; Wang, G.; Lu, C.; Gan, H.; Liu, Z. Evolution of deep parent fluids of geothermal fields in the Nimu-Nagchu geothermal belt, Tibet, China. Geothermics 2018, 71, 118-131. [CrossRef]

14. Wang, X.; Zhou, X.; Zheng, Y.; Song, C.; Long, M.; Chen, T.; Ren, Z.; Yang, M.; Li, X.; Guo, J. Hydrochemical characteristics and mixing behavior of thermal springs along the Bijiang River in the Lanping basin of China. Environ. Earth Sci. 2017, 76, 1-19. [CrossRef]

15. Tang, X.; Zhang, J.; Pang, Z.; Hu, S.; Wu, Y.; Bao, S. Distribution and genesis of the eastern Tibetan Plateau geothermal belt, western China. Environ. Earth Sci. 2016, 76. [CrossRef]

16. Zhang, Y.; Xu, M.; Li, X.; Qi, J.; Zhang, Q.; Guo, J.; Yu, L.; Zhao, R. Hydrochemical characteristics and multivariate statistical analysis of natural water system: A case study in Kangding county, southwestern China. Water 2018, 10, 80. [CrossRef]

17. Li, J.; Yang, G.; Sagoe, G.; Li, Y. Major hydrogeochemical processes controlling the composition of geothermal waters in the Kangding geothermal field, western Sichuan Province. Geothermics 2018, 75, 154-163. [CrossRef]

18. Qi, J.; Xu, M.; An, C.; Wu, M.; Zhang, Y.; Li, X.; Zhang, Q.; Lu, G. Characterizations of geothermal springs along the Moxi deep fault in the western Sichuan plateau, China. Phys. Earth Planet. Int. 2017, 263, $12-22$. [CrossRef]

19. Luo, J.; Pang, Z.; Kong, Y.; Wang, Y. Geothermal potential evaluation and development prioritization based on geochemistry of geothermal waters from Kangding area, western Sichuan, China. Environ. Earth Sci. 2017, 76, 1-24. [CrossRef]

20. Guo, Q.; Pang, Z.; Wang, Y.; Tian, J. Fluid geochemistry and geothermometry applications of the Kangding high-temperature geothermal system in eastern Himalayas. J. Appl. Geochem. 2017, 81, 63-75. [CrossRef] 
21. Wei, M.H.; Wang, J.; Tian, T. In Study of the Scaling Trend of Thermal Groundwater in Kangding County of Sichuan Province. Available online: https://pangea.stanford.edu/ERE/db/WGC/papers/WGC/2015/14059.pdf (accessed on 15 November 2019).

22. Chen, Z.; Zhou, X.; Du, J.; Xie, C.; Liu, L.; Li, Y.; Yi, L.; Liu, H.; Cui, Y. Hydrochemical characteristics of hot spring waters in the Kangding district related to the Lushan MS. 7.0 earthquake in Sichuan, China. Nat. Hazards Earth Sys. Sci. 2015, 15, 1149-1156. [CrossRef]

23. Wang, Y.; Pang, Z.; Hao, Y.; Fan, Y.; Tian, J.; Li, J. A revised method for heat flux measurement with applications to the fracture-controlled Kangding geothermal system in the Eastern Himalayan Syntaxis. Geothermics 2019, 77, 188-203. [CrossRef]

24. Li, B.; Shi, Z.; Wang, G.; Liu, C. Earthquake-related hydrochemical changes in thermal springs in the Xianshuihe Fault zone, Western China. J. Hydrol. 2019, 579. [CrossRef]

25. Shi, Z.; Liao, F.; Wang, G.; Xu, Q.; Mu, W.; Sun, X. Hydrogeochemical characteristics and evolution of hot springs in eastern Tibetan Plateau Geothermal Belt, western China: Insight from multivariate statistical analysis. Geofluids 2017, 2017, 6546041. [CrossRef]

26. Bai, M.; Chevalier, M.L.; Pan, J.; Replumaz, A.; Leloup, P.H.; Métois, M.; Li, H. Southeastward increase of the late Quaternary slip-rate of the Xianshuihe fault, eastern Tibet. Geodynamic and seismic hazard implications. Earth Planet. Sci. Lett. 2018, 485, 19-31. [CrossRef]

27. Piper, A.M. A graphic procedure in the geochemical interpretation of water-analyses. Eos Trans. AGU 1944, 25, 914-928. [CrossRef]

28. Giggenbach, W.F. Geothermal solute equilibria. Derivation of Na-K-Mg-Ca geoindicators. Geochim. Cosmochim. Acta 1988, 52, 2749-2765. [CrossRef]

29. Giggenbach, W.F.; Glover, R.B. Tectonic regime and major processes governing the chemistry of water and gas discharges from the rotorua geothermal field, New Zealand. Geothermics 1992, 21, 121-140. [CrossRef]

30. Truesdell, A.; Fournier, R. Procedure for estimating the temperature of a hot-water component in a mixed water by using a plot of dissolved silica versus enthalpy. USGS J. Res. 1977, 5, 49-52.

31. Wolfgang, W.; Hans-Joachim, K. International Steam Tables, Properties of Water and Steam Based on the Industrial Formulation IAPWS-IF97, 2nd ed.; Springer: Berlin, Germany, 1999; pp. 172-181. ISBN 978-3-540-21419-9.

32. Pang, Z.H.; Reed, M. Theoretical chemical thermometry on geothermal waters: Problems and methods. Geochim. Cosmochim. Acta 1998, 62, 1083-1091. [CrossRef]

33. Craig, H. Isotopic variations in meteoric waters. Science 1961, 133, 1702-1703. [CrossRef] [PubMed]

34. Song, C.L.; Sun, X.Y.; Wang, G.X. A study on precipitation stable isotopes characteristics and vapor sources of the subalpine Gongga Mountain, China. Resour. Environ. Yangtze Basin 2015, 24, 1860-1869. 